\title{
Metodologi Penelitian IImiah dan Alamiah
}

\author{
Oleh: Herry Widyastono")
}

\begin{abstract}
Abstrak: Metodologi penelitian dapat dibedakan antara metodologi penelitian kuantitatif (penelitian ilmiah) dan metodologi penelitian kualitatif (penelitian alamiah). Penelitian ilmiah pada umumnya menggunakan proses logika-hipotetiko-verivikatif, sedangkan penelitian alamiah pada umumnya menggunakan proses sirkuler. Kadangkala karena ketidaktahuan kita, kemudian kita mengidentifikasi diri sebagai penganut metode tertentu, dan dengan latah mengecam metode lainnya. Walaupun terdapat perbedaan antara kedua metode tersebul, tak ada faedahnya untuk mempertentangkannya bahkan memandangnya sebagai dua aliran yang bermusuhan. Yang perlu diperhatikan ialah bahwa ada masalah yang lebih sesuai diteliti dengan menggunakan penelitian ilmiah, ada pula masalah yang lebih sesuai diteliti dengan menggunakan penelitian alamiah. Penelitian ilmiah lebih menekankan pada pengukuran produk, sedangkan penelitian alamiah lebih menekankan pada pengukuran proses.
\end{abstract}

Kata kunci: metodologi, penelitian, ilmiah, alamiah, logika-hipotelikoverivikatif, sirkuler.

\section{Pendahuluan}

Dua paradigma penelitian, yaitu paradigma positivisme yang dirintis oleh Emile Durkheim (dalam Sumbangsih 1988) dan paradigma phenomenalogi yang dipelopori oleh Max Weber (dalam Sumbangsih 1988), yang lahir dalam periode bersamaan, telah mewariskan kepada generasi berikutnya untuk mengembangkan disiplin ilmu tingkah laku (behavioral science). Paradigma positivisme dikenal menggunakan metode kuantitatif(penelitian ilmiah), sedangkan paradigma phenomenologi menggunakan metode kualitatif (penelitian alamiah).

*) Dr. Herry Widyastono, Peneliti Madya Bidang Pendidikan, saat ini juga sebagai Kepala Bidang Kurikulum Pendidikan Khusus pada Pusat Kurikulum Badan Penelitian dan Pengembangan Depdiknas 
Karena itu tidak mungkin disusun rancangan penelitian yang rinci dan fixed sebelumnya. Rancangan penelitian berkembang selama proses penelitian berlangsung.

Peneliti cenderung mengumpulkan data melalui kontak terus menerus dengan orang-orang di dalam konteks yang natural dalam waktu yang lama. Peneliti berusaha memahami secara rinci bagaimana orang-orang yang dipelajari berfikir dan bagaimana mereka berkembang sampai kepada pandangan yang mereka yakini. Penelitian kualitatif lebih mengutamakan pemahaman makna tindakan manusia dalam saling tindaknya dengan sesama anggota masyarakat. Untuk maksud ini, seringkali peneliti harus menyediakan banyak waktu untuk bergaul secara informal dengan para subjek di lingkungan hidup mereka (Bogdan dan Biklen, 1982). Penelitian dan objek yang diteliti saling berinteraksi, yang proses penelitiannya dilakukan dari luar maupun dari dalam dengan banyak melibatkan judgment. Objek yang diteliti tidak lepas dari konteks waktu dan situasi sehingga penelitian cenderung berlangsung dalam setting/lingkungan nyata yang alamiah. Dalam pelaksanaanya, peneliti sekaligus berfungsi sebagai alat penelitian yang tentunya tidak bisa melepaskan diri sepenuhnya dari unsur subjektivitas. Dengan kata lain, dalam penelitian ini tidak ada alat penelitian baku yang telah disiapkan sebelumnya.

Hasil penelitian lebih merupakan deskripsi interpretasi yang bersifat tentatif dalam konteks waktu dan situasi tertentu. Kebenaran hasil penelitian lebih banyak didukung melalui kepercayaan (trustworthiness) berdasarkan konfirmasi hasil oleh pihak-pihak yang diteliti.

Istilah lain yang sering digunakan untuk penelitian kualitatif adalah penelitian alamiah, fild research (dalam penelitian antropologi) dan naturalistic (dalam penelitian pendidikan). Sedangkan istilah-istilah yang sering dihubungkan dengan penelitian alamiah adalah ethnographic approach, case study, dan phenomenological approach.

\subsection{Karakteristik dan ciri-ciri}

Penelitian alamiah berbeda dengan penelitian lainnya dalam beberapa hal. Bogdan dan Biklen (1982) mengidentifikasi 12 aspek perbedaan, yaitu: (1) afiliasi teoritik, (2) afiliasi akademik, (3) tujuan, (4) desain, (5) usulan penelitian, (6) data, (7) sampel, (8) teknik/metode, (9) hubungan penelitian dengan subjek, (10) instrumen/alat, (11) analisis data, dan 
(12) masalah dalam penggunuan metode. Zaini Hasan M (1990) mengulas beberapa di antara sekian banyak perbedaan tersebut seperti di bawah ini.

Penelitian alamiah pada umumnya berangkat dari teori-teori phenomenologi, idealisme, interaksi simbolik, atau etnometodologi. Sedangkan penelitian ilmiah bertolak dari teori-teori behaviorisme, fungsionalisme struktural, realisme, positivisme, atau empirisme logis. Dalam bidang Ilmu Sosial, afiliasi akademik penelitian alamiah adalah antropologi, sosiologi, dan sejarah. Sedangkan afiliasi akademik penelitian ilmiah adalah ekonomi, psikologi, sosial, dan ilmu politik. Tujuan penelitian alamiah berada pada lingkup pengembangan konsep, pengembangan pemahaman, deskripsi multi realitas, dan pengembangan teori yang bersifat grounded. Sedangkan tujuan penelitian ilmiah untuk menguji teori, menyajikan fakta, deskripsi statistik, menunjukkan hubungan antarvariabel, atau prediksi.

Dalam penelitian alamiah, desain penelitian bersifat umum, luwes, selalu berkembang, dan biasanya terbatas pada bagaimana peneliti akan memulai kegiatannya. Sedangkan dalam penelitian ilmiah lebih spesifik, terstruktur, formal, dan lengkap sampai pada rincian operasionalnya. Konsekuensi desain yang demikian, usulan (proposal) penelitian dengan penelitian alamiah bersifat spekulatif, tak banyak kajian literatur, dan sering ditulis setelah sebagian data dikumpulkan. Sedangkan proposal penelitian ilmiah bersifat lebih lengkap, rinci dengan fokus dan prosedur yang lebih spesifik, kajian literatur lebih lengkap, hipotesis sudah dirumuskan dengan jelas dan dapat ditulis sebelum data dikumpulkan.

Beberapa metode/teknik yang banyak diterapkan dalam penelitian alamiah adalah participant observation, open-ended interviewing, dan dokumentasi. Sedangkan dalam penelitian ilmiah sering menggunakan eksperimen, survei, observasi terstruktur, dan wawancara terstruktur. Alat pengumpul data dalam penelitian alamiah biasanya hanya alat tulis, tape recorder, dan kamera, di samping peneliti sendiri. Sedangkan dalam penelitian ilmiah sering menggunakan angket, pedoman wawancara, alat ukur yang baku, atau format observasi. Dalam penelitian alamiah analisis data dilakukan sambil jalan, secara induktif analitik, dan metode constant comparation. Sedangkan dalam 
penelitian ilmiah data dianalisis secara deduktif dengan prosedur statistik.

Burgess (1985) mengidentifikasi sejumlah istilah yang dapat membedakan antara penelitian alamiah dengan penelitian ilmiah sebagai berikut.

\begin{tabular}{|l|l|}
\hline \multicolumn{1}{|c|}{ QUALITATIVE } & QUANTITATIVE \\
\hline soft & hard \\
dry & wet \\
flexible/fluid & fixed \\
grounded & abstract \\
descriptive & explanatory \\
pre-scientific & scientific \\
subjective & objective \\
inductive & deductive \\
speculative/illustrative & hypothesis-testing \\
political & value-free \\
non-rigorous & rigorous \\
& \\
\hline
\end{tabular}

Sedangkan menurut Williams (1988), penelitian alamiah berbeda dengan penelitian lainnya (penelitian ilmiah) dalam tiga hal pokok, yaitu: (a) pandangan-pandangan dasar (axioms) tentang hakikat realitas, hubungan peneliti dengan yang diteliti, kemungkinan generalisasi, kemungkinan hubungan sebabakibat, serta peranan nilai dalam penelitian; (b) karakteristik penelitian alamiah itu sendiri; dan (c) proses yang diikuti untuk melaksanakan penelitian.

\section{a. Pandangan-pandangan dasar}

Perbedaan pandangan dasar (axioms) antara penelitian alamiah dengan penelitian ilmiah dapat dibuat secara diagramatis sebagai berikut (Williams, 1988; Lincoln dan Guba, 1985):

\begin{tabular}{|l|l|l|}
\hline SUDUT PANDANG & Penelitian alamiah & Penelitian ilmiah \\
\hline 1. Hakikat realitas & $\begin{array}{l}\text { Realitas itu bersifat } \\
\text { ganda, dibentuk, dan } \\
\text { merupakan keutuhan }\end{array}$ & $\begin{array}{l}\text { Realitas itu tunggal, } \\
\text { konkret teramati, dan } \\
\text { dapat dipragmentasikan }\end{array}$ \\
\hline $\begin{array}{l}\text { 2. Hubungan peneliti } \\
\text { dengan yang diteliti }\end{array}$ & $\begin{array}{l}\text { Interaktif, tak dapat } \\
\text { dipisahkan }\end{array}$ & $\begin{array}{l}\text { Independen, suatu } \\
\text { dualisme }\end{array}$ \\
\hline $\begin{array}{l}\text { 3. Kemungkinan } \\
\text { generalisasi }\end{array}$ & $\begin{array}{l}\text { Bergantung pada konteks } \\
\text { dan waktu }\end{array}$ & $\begin{array}{l}\text { Tidak bergantung pada } \\
\text { konteks dan waktu }\end{array}$ \\
\hline $\begin{array}{l}\text { 4. Kemungkinan } \\
\text { hubungan } \\
\text { akibat }\end{array}$ & $\begin{array}{l}\text { Sulit memisahkan sebab } \\
\text { dengan akibat karena } \\
\text { pada semua keadaan } \\
\text { terjadi secara simultan }\end{array}$ & $\begin{array}{l}\text { Terdapat penyebab riil } \\
\text { yang secara temporal } \\
\text { atau simultan senantiasa } \\
\text { mendahului dan } \\
\text { melahirkan akibat }\end{array}$ \\
\hline 5. Peranan nilai & Tidak bebas nilai & \begin{tabular}{l} 
Bcbas nilai \\
\hline
\end{tabular} \\
\hline
\end{tabular}




\section{b. Karakteristik penelitian alamiah}

Penelitian alamiah memiliki sejumlah ciri yang membedakannya dengan metode yang lain. Bogdan dan Biklen (1982) mengajukan lima buah ciriyang merupakan karakteristik penelitian alamiah pada umumnya, yaitu: (1) natural setting sebagai sumber data langsung dan peneliti sebagai instrumen kunci, (2) bersifat deskriptif, (3) lebih mengutamakan proses daripada hasil, (4) analisis data secara induktif, dan (5) makna merupakan perhatian utamannya.

Sedangkan Lincoln dan Guba (1985) mengulas sepuluh buah ciri. Kemudian Molcong (1989) menguraikan 11 ciri yang merupakan hasil analisis dan sintesis dari pendapat Bogdan dan Biklen (1982) serta Lincoln dan Guba (1985). Beberapa ciri yang belum termasuk dalam lima butir Bogdan dan Biklen di atas antara lain adalah: (1) desain yang bersifat sementara, (2) pengambilan sampel secara purposif, dan (3) hasil yang dinegosiasikan.

Selanjutnya Williams (dalam Faisal, 1990) menerangkan adanya tiga belas ciri sebagai berikut: (1) Pengumpulan data dilakukan dalam latar alamiah (natural setings). Peneliti menelaah gejala-gejala sosialbudaya dalam suasana yang berlangsung secara alamiah, bukan dalam kondisi yang terkendali seperti penelitian di laboratorium, (2) Peneliti merupakan instrumen utama dalam mengumpulkan dan menginterpretasikan data. Instrumen lain, misalnya angket hanya merupakan alat bantu (bila memang diperlukan), bukan pengganti peneliti, (3) Kaya dan sarat dengan deskripsi. Peneliti yang terdorong untuk memahami fenomena secara menyeluruh tentunya harus memahami segenap konteks dan melakukan analisis holistik, yang tentunya perlu dideskripsikan, (4) Meskipun penelitian kualitatif sering memperhatikan hasil dan akibat dari berbagai variabel yang saling membentuk secara simultan, namun lebih lazim menelaah proses-proses yang terjadi, termasuk di dalamnya bagaimana berbagai variabel saling membentuk dan bagaimana orangorangnya saling berinteraksi dalam latar alamiah yang menjadi medan penelitian, (5) Kebanyakan penelitian kualitatif menggunakan analisis induktif, terutama pada tahap-tahap awalnya. Dengan demikian akan terbuka kemungkinan munculnya masalah dan fokus penelitian pada hal-hal yang memang mendesak dan bernilai. Jadi peneliti tidak berpegang pada masalah yang telah dibatasi sebelumnya (pre-defined issues). 
Walau demikian, analisis deduktifjuga digunakan, khususnya pada fase-fase belakangan, (6) Makna di balik tingkah laku manusia merupakan hal esensial bagi penelitian kualitatif. Peneliti tidak hanya tertarik pada apa yang dikatakan atau dilakukan manusia yang satu terhadap manusia lainnya, tetapi juga pada maknanya dalam sudut pandangan mereka masingmasing, (7) Menuntut sebanyak mungkin kepada penelitinya untuk melakukan sendiri kegiatan penelitian di lapangan. Ini tidak hanya akan membantu peneliti dalam memahami konteks dan berbagai perspektif dari orang yang sedang diteliti, tetapi juga supaya mereka yang diteliti menjadi lebih terbiasa dengan kehadiran peneliti di tengah-tengah mereka, sehingga efek pengamatan (the observer effects) menjadi seminimal mungkin, (8) Terdapat kegiatan triangulasi yang dilakukan secara ekstensif, baik triangulasi metode (mengunakan lintas metode dalam pengumpulan data), maupun triangulasi sumber data (memakai beragam sumber data yang relevan), dan triangulasi pengumpulan data (beberapa peneliti yang mengumpulkan data secara terpisah). Hal ini dilakukan sebagai upaya verifikasi atas data yang ditemukan, (9) Orang yang diteliti diperhitungkan sebagai partisipan, konsultan, atau kolega peneliti dalam menangani kegiatan penelitian. Jarang, orang yang distudi tersebut dianggap sebagai subjek apalagi objek penelitian, (10) Perspektif emic partisipan sangat diutamakan dan dihargai tinggi dalam penelitian alamiah. Minat peneliti banyak tercurah pada bagaimana persepsi dan makna-makna menurut sudut pandang partisipan yang sedang diteliti sehingga bisa menemukan apa yang disebut dengan fakta fenomenologis, (11) Hasil/temuan peneliti jarang dianggap sebagai temuan final sepanjang belum ditemukan bukti-bukti kuat yang tak tersanggah melalui buktibukti penyanggah (contrary evidence). Bila belum sampai ketingkat itu, penelitian kualitatif biasanya sekedar mengajukan hipotesis yang belum secara final teruji, (12) Pengambilan sampel biasanya dilakukan secara purposif rasional (logical, purposive samping). Di sini, peneliti harus dapat menjelaskan mengapa orang-orang tertentu yang dijadikan sampel, serta mengapa latar-latar tertentu yang diobservasi, dan (13) Baik data kuantitatif maupun data kualitatif dalam penelitian alamiah sama-sama 
digunakan. Penelitian alamiah menolak data yang menunjuk pada seberapa banyak dari sesuatu.

\section{c. Proses Penclitian}

\section{1) Penelitian ilmiah}

Penelitian ilmiah pada umumnya menggunakan proses logikahipotetiko-verivikatif dengan langkah-langkah sebagai berikut.

\section{Langkah pertama}

Langkah pertama dalam penelitian ilmiah adalah mengajukan masalah. Pada hakikatnya, suatu masalah tidak pernah berdiri sendiri malainkan musti terdapat konstelasi yang merupakan penyebab atau latar belakang timbulnya masalah tersebut. Berdasar latar belakang masalah tersebut dapat diidentifikasi berbagai permasalahan yang timbul. Dari permasalahan yang telah diidentifikasi, yang ternyata dapal ditemukan banyak permasalahan, maka diperlukan pembatasan masalah. Berdasar pembatasan masalah tersebut, peneliti dapat merumuskan masalah yang merupakan pertanyaan mengenai objek empiris yang jelas batasbatasnya serta dapat diidentifikasi faktor-faktor yang terkait di dalamnya. Setelah masalah berhasil dirumuskan, maka tahap berikutnya peneliti menyatakan tujuan penelitian dan kegunaan penelitian yang dilakukan. Tujuan dan Kegunaan penelitian ini perlu dikemukakan, karena sekiranya penelitian yang akan dilakukan tidak ada tujuan dan kegunaannya, maka si peneliti akan sia-sia, alias mubazir saja melakukan penelitiannya.

Dengan demikian, langkah pengajuan masalah (yang dalam penulisan laporan penelitian biasanya masuk dalam bab I pendahuluan) secara kronologis dapat dijabarkan ke dalam enam kegiatan, yaitu: (1) latar belakang, (2) identifikasi masalah, (3) pembatasan msalah, (4) perumusan masalah, (5) tujuan penelitian, dan (6) kegunaan penelitian.

\section{Langkah kedua}

Setelah masalah berhasil dirumuskan, maka langkah berikutnya adalah mengajukan hipotesis, yang merupakan ramalan jawaban terhadap masalah yang diajukan.

Dalam meramalkan jawaban, kemungkinan besar tidak akan benar jawaban tersebut sekiranya tidak berlandaskan pada teori-teori ilmiah yang ada. Misalnya, kita dapat menjawab $4 \times 4=16$, karena kita sudah mengerti teori perkalian; sedangkan 
seorang anak kecil yang belm bersekolah, bila ditanya $4 \times 4$ mungkin dengan seenaknya akan menjawab seribuuuu. Ini berarti bahwa sebelum kita memberikan jawaban terhadap rumusan masalah yang diajukan, sekiranya kita ingin jawaban kita benar, sudah barang tentu kita musti mempelajari terlebih dulu teori-teori yang berhubungan dengan masalah tersebut. Hal ini menunjukkan perlunya terlebih dulu mengkaji teori-teori ilmiah yang berhubungan dengan masalah yang diajukan, sebelum kita mencoba memberi jawabannya, agar jawabannya benar.

Berdasar analisis terhadap teoriteori para ahli dapat dirumuskan definisi konseptual dari variable yang diteiliti, dimensi, subvariabel, dan indikator dari variabel tersebut.

Selanjutnya, berdasar kajian teori tersebut, kita dapat menyusun kerangka berpikir, yang merupakan argumentasi yang menjelaskan hubungan yang mungkin terdapat antara berbagai faktor yang saling berkait dan membentuk konstelasi permasalahan. Kemudian, berdasar kajian teori dan kerangka berpikir tersebut, kita dapat merumuskan hipotesis, yang merupakan jawaban sementara terhadap rumusan masalah pada bab sebelumnya.
Dengan demikian, langkah pengajuan hipotesis (yang dalam penulisan laporan penelitian biasa masuk dalam bab II landasan teoritik, kerangka berpikir, dan pengajuan hipotesis) dapat dibagi dalam kagiatan-kegiatan: (1) pengkajian teori-teori ilmiah yang relevan, (2) penyusunan kerangka berfikir, dan (3) perumusan hipotesis.

\section{Langkah ketiga}

Setelah hipotesis berhasil dirumuskan, maka langkah berikutnya adalah menguji hipotesis. Pengujian hipotesis dilakukan dengan verifikasi apakah hipotesis yang diajukan didukung oleh fakta atau tidak. Dalam. pengujian hipotesis ini, masalah yang dihadapi adalah bagaimana prosedur penelitian dilakukan, dan cara pengumpulan serta analisis data, agar kesimpulan yang ditarik memenuhi persyaratan ilmiah. Penetapan prosedur penelitian, dan cara pengumpulan serta analisis data ini dibahas dalam metodologi penelitian yang merupakan langkah persiapan sebelum pengujian dilakukan.

Sebelum pengujian dilakukan, perlu dikemukakan terlebih dahulu mengenai tempat dan waktu penelitian. Hal ini dimaksudkan untuk menentukan tingkat keumuman 
(level of generality) dari kesimpulan yang akan ditarik, seperti tempat, waktu, kelembagaan. Setelah itu, dinyatakan metode penelitiannya. Selanjutnya, dinyatakan teknik pengambilan sampelnya. Kemudian dinyatakan teknik pengumpulan data, instrument penelitian, dan ujicoba instrumennya. Berikutnya dinyatakan teknik analisis datanya.

Dengan demikian, dalam penulisan metodologi penelitian (yang dalam penulisan laporan penelitian lazim ditulis bab III metodologi penelitian) perlu dinyatakan: (1) tempat dan waktu penelitian (2) metode Penelitian, (3) teknik pengambilan sampel, (4) teknik pengumpulan data, (5) instrumen penelitian, (6) ujicoba instrument, dan (7) teknik analisis data.

\section{Langkah keempat}

Setelah mctodologi penelitian yang merupakan langkah persiapan sebelum pengujian dilakukan selesai dipersiapkan, kemudian kita melakukan pengujian dengan cara verifikasi dengan keadaan lapangan, dengan fakta empiris.Bila pengujian telah selesai dilakukan, maka sampailah kita pada langkah berikutnya yakni melaporkan apa yang kita temukan berdasarkan hasil penelitian di lapangan.

Secara kronologis, hasil penelitian (yang dalam penulisan laporan penelitian lazim ditulis bab IV hasil penelitian dapat dijabarkan ke dalam langkah-langkah: (1) mendeskripsikan data penelitian, (2) melakukan pengujian persyaratan analisis, (3) melakukan pengujian hipotesis, termasuk di dalamnya memberikan interpretasi (penafsiran) tcrhadap hasil pengujian hipotesis, dan (4) membahas hasil penelitian.

\section{Langkah kelima}

Selanjutnya, berdasar hasil penelitian di atas kita dapat menarik simpulan yang merupakan sintesis dari berbagai penemuan penelitian. Kemudian berdasar simpulan tersebut kita dapat mengemukakan implikasinya serta memberikan saran yang rinci dan bersifat operasional. Langkah ini dalam penulisan laporan penelitian lazim ditulis bab $V$ simpulan dan saran.

Semua langkah dan kegiatan di atas dapat dibuat secara diagramatis seperti di bawah ini (Widyastono, 1989, adaptasi dari Suriasumantri, 1985). 


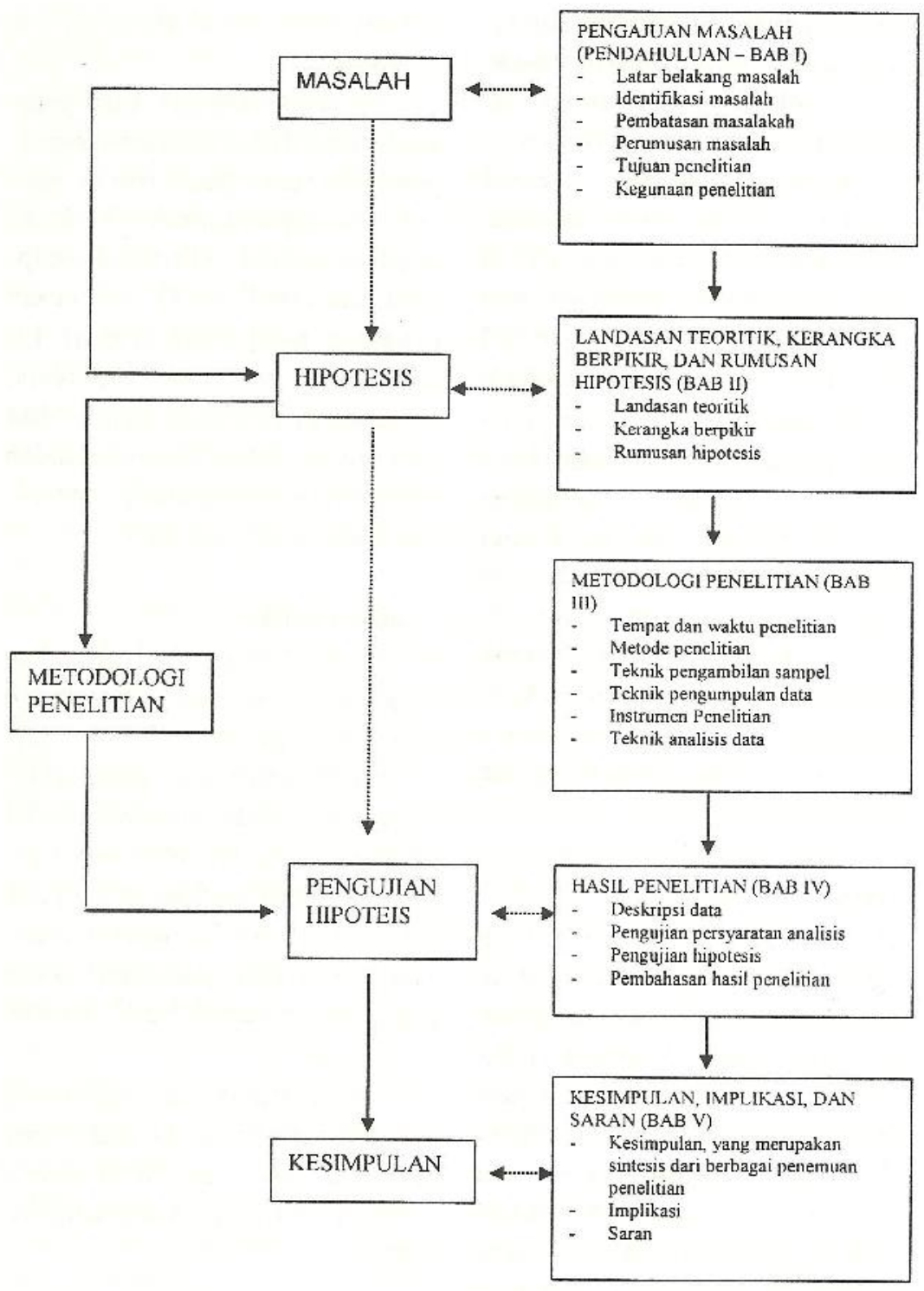

\section{Langkah dan Kegiatan Penelitian Ilmiah}




\section{2) Penelitian alamiah}

Penelitian alamiah pada umumnya menggunakan proses sirkuler, mengikuti jalan lingkaran tanpa putus-putusnya (Nasuttion, 1988), dengan kegiatan (langkah-langkah) seperti di bawah ini.

Pada taraf permulaan masih ada persamaan dengan penelitian ilmiah. Peneliti menaruh minat terhadap suatu topik yang pada mulanya masih bersifat umum. Peneliti harus mempunyai alasan mengapa ingin menelitinya

Berkenan dengan topik itu, kemudian peneliti dapat merumuskan sejumlah pertanyaan pendahuluan (umum). Dari pertanyaan umum tersebut, selanjutnya peneliti mengidentifikasi sejumlah informasi yang kira-kira diperlukan.

Selajutnya, peneliti menentukan metode/teknik pengumpulan data apa yang akan digunakan. Biasanya berupa observasi dan wawancara, tetapi juga dokumen dan bacaan lainnya.

Dengan persiapan yang masih umum dan belum terinci itu, peneliti memasuki lapangan. Bahkan masalah apa yang akan menjadi pokok penelitiannya masih samarsamar pada saat itu, namun akan menjadi lebih jelas waktu peneliti masuk latar penelitian. Sebaliknya, ada kemungkinan topik harus dirubah kalau ternyata lapangan yang dipilih tidak dapat memberikan data yang diperlukan. Dalam hal ini peneliti dapat mencari lokasi baru, yang belum pasti memenuhi syarat juga. Bila peneliti berada di lokasi itu beberapa waktu, diharapkan akan ditemukan topik yang cocok. Itu sebabnya maka dikatakan bahwa desain penelitian kualitatif adalah emergent. Peneliti merumuskan masalahnya secara lebih spesifik bergantung pada apa yang terjadi di lapangan. Bisa terjadi masalah berubah sesuai dengan kondisi dan situasi di lapangan.

Di lapangan, peneliti mengadakan pengumpulan data dengan observasi sambil mencatat hal-hal yang diamati. Alat yang digunakan sering hanya buku catatan dan alat tulis. Apa yang diamatinya bergantung pada keputusannya sendiri. Banyak yang dapat diamatinya, baik mengenai orang yang berada di situ, kegiatankegiatan, lingkungan fisiknya, dan sebagainya. Peneliti harus memilih sendiri, jadi mengadakan sampling tentang apa yang akan diberinya perhatian. Penentuan sampling ini akan berlangsung terus selama peneliti melaksanakan penelitian. 
Informasi perlu selalu dicek kebenarannya agar hasil penelitiannya dapat dipercaya, dengan cara berusaha memperoleh informasi dari beberapa pihak. Ini disebut triangulasi. Tujuannya ialah memverifikasi atau mengkonformasi informasi. Data yang diperoleh segera dianalis untuk mencari maknanya, walaupun masih bersifat tentatif (belum final). Data yang telah dianalisis, kemudian ditinjau kembali berdasarkan verifikasi dengan data yang diperoleh kemudian. Jadi dalam penelitian alamiah, pengumpulan data dan analisis data dapat berjalan serentak/sekaligus.

Setelah data dianalisis dan diverifikasi, kemudian segera disusun dalam bentuk laporan. Laporan hendaknya disusun setiap saat, dan jangan sampai dilewatkan sejenakpun. Berdasarkan laporan tersebut, mungkin akan timbul sejumlah pertanyaan baru, yang menjadi pegangan untuk mengadakan observasi dan wawancara berikutnya. Data yang kemudian diperoleh, kembali dianalisis dan dituangkan dalam bentuk laporan. Penulisan laporan mungkin menimbulkan pertanyaan baru lagi yang menjadi dorongan bagi penelitian selanjutnya, demikian seterusnya.
Proses ini berjalan terus tanpa ada akhirnya. Oleh karena itu disebut sirkuler, mengikuti jalan lingkaran tanpa putus-putus. Namun, kegiatan penelitian pada suatu saat harus disudahi, misalnya bila hasilnya telah dianggap memadai atau memuaskan, atau bila penelitian telah sampai pada taraf ketuntasan sehingga hampir tidak timbul lagi hal-hal yang baru (datanya sudah jenuh). Sering pula penelitian harus diakhiri karena terbatasnya sumber daya.

Langkah-langkah di atas dapat dibuat secara diagramatis seperti berikut (Nasution, 1988). 


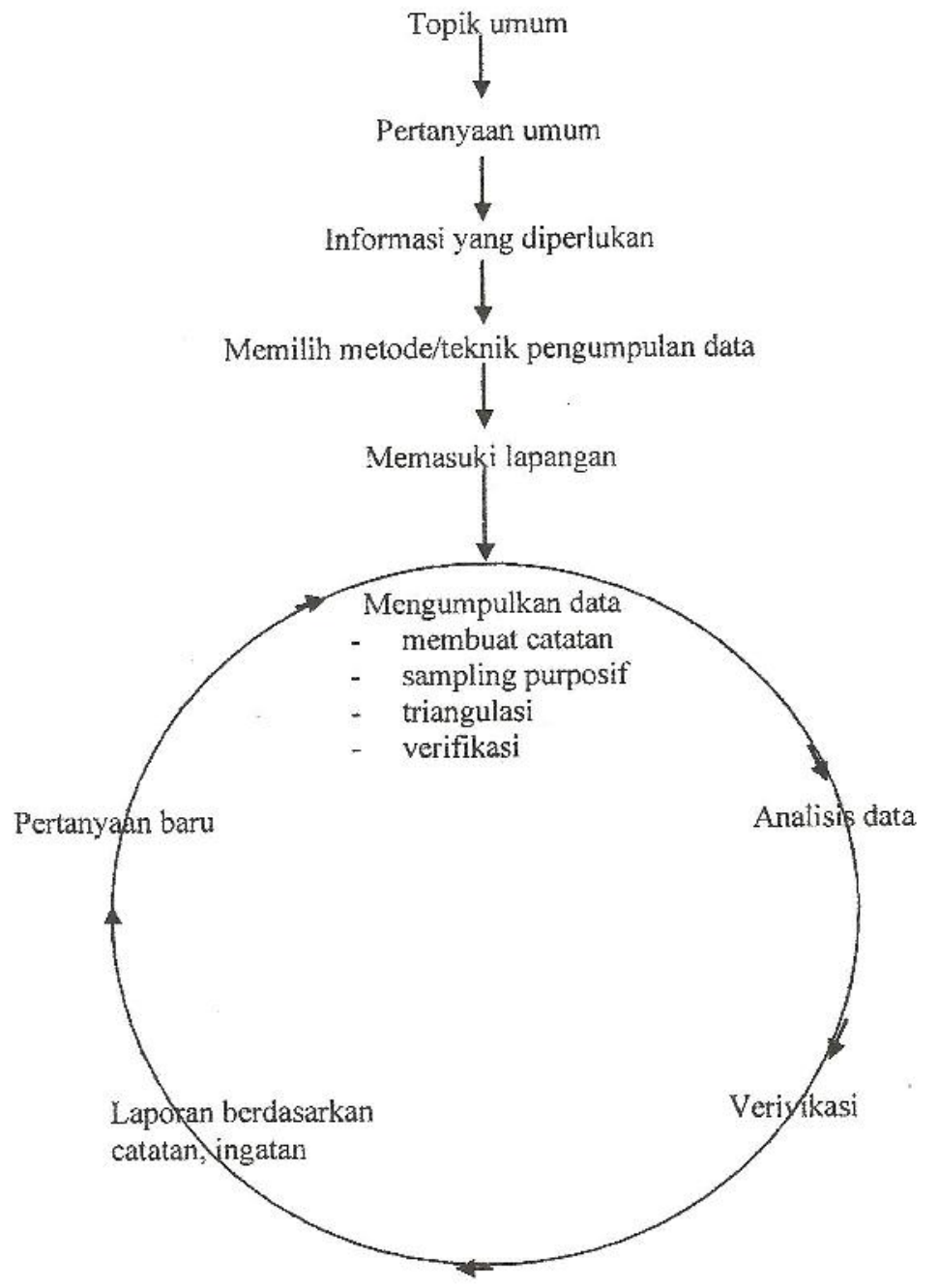

Desain Sirkuler 
Berdasar uraian di atas, penulisan laporan penelitian kualitatif dapat disistematisir menjadi langkahlangkah di bawah ini.

\section{Langkah pertama}

Langkah pertama, mengajukan masalah. Langkah pengajuan masalah (yang dalam penulisan laporan penelitian biasanya masuk dalam bab I pendahuluan) sama halnya dengan penelitian ilmiah, secara kronologis dapat dijabarkan ke dalam enam kegiatan, yaitu: (1) latar belakang, (2) identifikasi masalah (ada literatur yang menyebut dengan istilah fokus penelitian), (3) pembatasan penelitian, (4) perumusan masalah (ada literatur yang menyebut dengan istilah pertanyaan penelitian), (5) tujuan penelitian, dan (6) kegunaan penelitian.

\section{Langkah kedua}

Setelah masalah dirumuskan, maka langkah berikutnya adalah studi pustaka (kajian literatur) yang dimaksudkan agar peneliti memahami berbagai faktor yang terkait dengan masalah yang akan ditelitinya. Berdasar kajian literatur, selanjutnya disusun pertanyaan penelitian. Dalam penulisan laporan penelitian biasanya dimasukkan dalam bab II kajian literatur dan pertanyaan penelitian, yang terdiri atas kegiatan: (1) kajian literatur, dan (2) pertanyaan penelitian.

\section{Langkah ketiga}

Berdasar pertanyaan penelitian tersebut, selanjutnya peneliti ingin mendapatkan jawabannya berdasar kenyataan di lapangan, dengan cara terjun ke lapangan, yang biasanya dilakukan dengan observasi, wawancara, dan kajian terhadap dokumen yang ada. Pada saat terjun ke lapangan, masalah yang dihadapi adalah bagaimana prosedur penlitian dilakukan, dan cara pengumpulan serta analisis datanya, agar kesipulan yang ditarik betul-betul sesuai dengan kondisi yang ada, bukan hasil rekayasa (overacting). Penetapan prosedur penelitian, dan cara pengumpulan serta analisis data ini dibahas dalam metodologi penelitian yang merupakan langkah persiapan sebelum terjun ke lapangan.

Sebelum terjun ke lapangan, perlu dikemukakan terlebih dahulu mengenai tempat dan waktu penelitian, dimaksudkan untuk menentukan ruang lingkup dari kesimpulan yang akan ditarik. Setelah itu, dinyatakan metode penelitiannya, misalnya penelitian evaluatif, naturalistik, grounded research, atau jenis lainnya. 
Selanjutnya, dinyatakan teknik pengambilan sampelnya, biasanya dengan teknik purposif sampling. Kemudian dinyatakan instrumen penelitiannya, biasanya instrumen penelitiannya adalah peneliti yang bersangkutan; disertai teknik pengumpulan data, biasanya berupa pedoman observasi, pedoman wawancara, atau sejenisnya; bahkan ada yang hanya paper and pen. Berikutnya dinyatakan kriteria dan teknik pemeriksaan keabsahan data, dan teknik analisis data.

Dengan demikian, dalam penyusunan metodologi penelitian yang merupakan langkah persiapan sebelum terjun ke lapangan (yang dalam penulisan laporan penelitian biasa dimasukkan dalam bab III metodologi penelitian) perlu dinyatakan: (1) tempat dan waktu penelitian (2) metode penelitian, (3) teknik pengambilan sampel, (4) Instrumen penelitian, (5) teknik pengumpulan data, (6) kriteria dan teknik pemeriksaan keabsahan data, dan (7) keknik analisis data.

\section{Langkah keempat}

Setelah metodologi penelitian selesai dipersiapkan, kemudian kita terjun ke lapangan melakukan pengumpulan data, pemeriksaan keabsahan data, analisis data, yang dilakukan secara berulang-ulang sampai diperoleh hasil yang relatif stabil (datanya jenuh).

Bila semua tahapan telah selesai dilakukan, maka sampailah kita kepada langkah berikutnya yakni melaporkan apa yang kita temukan berdasarkan hasil penelitian di lapangan. Secara kronologis, hasil penelitian (yang dalam penulisan laporan penelitian biasa masuk dalam bab IV hasil penelitian dapat dijabarkan ke dalam langkah-langkah: (1) mendeskripsikan data penelitian (temuan), (2) mendeskripsikan hasil analisis data, (3) melakukan interpretasi (penafsiran) dan penjelasan temuan penelitian, (4) membahas temuan penelitian.

\section{Langkah kelima}

Selanjutnya, berdasar hasil penelitian di atas kita dapat menarik simpulan yang merupakan sintesis dari berbagai penemuan penelitian. Kemudian berdasar simpulan tersebut kita dapat mengemukakan implikasinya serta memberikan saran yang terinci dan bersifat operasional. Langkah ini dalam penulisan tesis biasa masuk dalam bab V simpulan, implikasi, dan saran. 


\section{Simpulan dan Saran}

\subsection{Simpulan}

Penelitian alamiah berbeda dengan penelitian ilmiah dalam tiga hal pokok, yaitu: (a) Pandangan-pandangan dasar (axioms) tentang hakikat realitas, hubungan peneliti dengan yang diteliti, kemungkinan generalisasi, kemungkinan hubungan sebab-akibat, serta peranan nilai dalam penelitian; (b) Karakteristik penelitian; dan (c) Proses yang diikuti untuk melaksanakan penelitian.

\subsection{Saran}

Walaupun terdapat perbedaan antara kedua metode penelitian di atas, tak ada faedahnya untuk mempertentangkannya bahkan memandangnya sebagai dua ahiran yang bermusuhan. Yang perlu diperhatikan ialah bahwa ada masalah yang lebih sesuai diteliti dengan menggunakan penelitian ilmiah; ada pula masalah yang lebih sesuai diteliti dengan menggunakan penelitian alamiah. Metode apa yang akan digunakan tergantung pada jenis masalahnya. Bila masalahnya bersifat kuantitatif, maka yang sesuai digunakan ialah penelitian ilmiah; sedangkan jika masalahnya bersifat kualitatif, maka yang cocok digunakan yaitu penelitian alamiah.

\section{Pustaka Acuan}

Burgess, R.G. 1985. Strategies of Educational Research: Qualitative Methods. London: The Palmer Press.

Bogdan, R.C. \& Biklen, S.K. 1982. Qualitative Research for Education: An Introduction to Theory and Methods. Boston: Allyn and bacon, Inc.

Faisal, Sanapiah. 1990. Penelitian Kualitatif: Dasar-dasar dan Aplikasi. Malang: Yayasan Asih Asah Asuh.

Lincoln, Y.S \& Guba, E.G. 1985. Naturalistic Inquiry. Beverly Hills: Sage Publicatons.

Moleong, Lexy J. 1989. Metodologi Pebnelitian Kualitatif. Bandung: Remaja Karya.

Nasution, S. 1988. Metode Penelitian Naturalistik Kualitatif. Bandung: Tarsito.

Sudjana, Nana., dan Ibrahim. 1989. Penelitian dan Penilaian Pendidikan. Bandung: Sinar Baru.

Sumbangsih-Jurnal Penelitian UNS. 1988. Tajuk Rencana. Surakarta: Pusat Penelitian Univeritas sebelas Maret. 
Suriasimantri, Jujun S. 1985. Filsafat llmu-Sebuah Penganiar Populer. Jakarta: Sinar Harapan.

Widyastono, Herry. 1989. Sumber Pengetahuan, Struktur Penelitian dan Penulisan Ilmiah, serta Berbagai Permasalahannya, Majalah Ilmiah KAIS - Kajian Ilmu Sosial No. 01. Jakarta FISIP Universitas Muhammadiyah Jakarta.

Williams, D.C. 1988. Naturalistic Inquiry Materials. Bandung: FPS IKIP Bandung.

Zaini Hasan, M. 1990. Karakteristik Penelitian Kualitatif. Malang: Yayasan Asih Asah Asuh. 